\title{
Past changes in Atlantic Ocean circulation at intermediate water depths from micropaleontological and geochemical proxies since the last glacial maximum
}

\author{
SOLÈNE POURTOUT ${ }^{1}$, SOPHIE SEPULCRE ${ }^{2}$, \\ CHRISTOPHE COLIN ${ }^{1}$, LAËTITIA LICARI ${ }^{3}$, GIUSEPPE \\ SIANI $^{1}$ AND ELISABETH MICHEL ${ }^{4}$ \\ ${ }^{1}$ University Paris-Saclay \\ ${ }^{2}$ Université Paris Saclay GEOPS-CNRS UMR 8148 \\ ${ }^{3}$ University Aix-Marseille \\ ${ }^{4}$ Laboratoire des Sciences du Climat et de l'Environnement \\ (LSCE/IPSL), Gif-sur-Yvette \\ Presenting Author: solene.pourtout@universite-paris-saclay.fr
}

Ocean circulation plays a central role on climate regulation. The paleoceanographic studies of the last decades have allowed to better document the variations in the production of the North Atlantic Deep Water (NADW). However, the role of intermediate water (IW) masses through time remains to be documented and is highly controversial. Indeed, some studies have highlighted the increased contribution of the Antarctic Intermediate Water (AAIW) in all ocean basins during the cold events recorded in the North Atlantic [1] while others suggest their absence [2]. Moreover, during the last deglaciation, the Southern Ocean played a fundamental role in the Carbon transfer from the deep ocean to the atmosphere via the increased upwelling associated to the AAIW production. In order to reconstruct the dynamics of IW masses, to better understand the relationships between variations in ocean circulation in the Atlantic and in the Southern Ocean, and the impact of these changes on the global carbon cycle during Termination I, we use two marine sediment cores from the Porcupine basin MD012461 (1153m) and the Iberian margin SU92-28 (997m). We combine the study of benthic foraminifera assemblages sensitive to variations in their environment (nutrient content, oxygen), and different geochemical proxies such as elemental ratios $(\mathrm{Mg} / \mathrm{Ca}$, $\mathrm{Sr} / \mathrm{Ca}, \mathrm{Cd} / \mathrm{Ca}, \mathrm{Ba} / \mathrm{Ca}, \mathrm{B} / \mathrm{Ca}, \mathrm{Li} / \mathrm{Ca}$ and $\mathrm{U} / \mathrm{Ca}$ ), stable isotopes $\left(\delta^{18} \mathrm{O}\right.$ and $\left.\delta^{13} \mathrm{C}\right)$ and Neodymium isotopes records $(\mathrm{eNd})$. On core SU92-28, past changes in the benthic foraminiferal content exhibit strong differences in the paleo-environments, with different ecological conditions from the LGM to the Holocene, as well as during the YD and $\mathrm{H} 1$ events. These differences are also observed in the $\delta^{13} \mathrm{C}$ and elemental ratio records obtained from Uvigerina peregrina and Cibicidoides mundulus. Changes in the eNd record allow to distinguish changes in the IW mass sources, reflecting the balance between Northern and Southern contributions. Future analysis (e.g., ${ }^{14} \mathrm{C}$ reservoir ages) and the comparison with core MD01-2461 records will help to better constrain the North-South connections in the Atlantic Ocean at IW depths, and their impact on global climate changes.

[1] Ma et al. (2019) Geochemistry, Geophysics, Geosystems, 20(3), 1592-1608

[2] Gu, S., et al. (2017). Paleoceanography, 32, 1036-1053. 